\title{
Environmental assessment of the Sibiu County, Romania: proposal for sewage sludge and OFMSW management
}

\author{
Gloria Trombin ${ }^{1}$, Marco Ragazzi ${ }^{1}$, Claudiu Isarie $^{2}$, Rodica Ciudin $^{2}$, and Vincenzo Torretta ${ }^{3, *}$ \\ ${ }^{1}$ Department of Civil and Environmental Engineering, University of Trento, Trento, Italy \\ ${ }^{2}$ Department of Industrial Engineering and Management, Lucian Blaga University of Sibiu, Sibiu, \\ Romania \\ ${ }^{3}$ Department of Theoretical and Applied Sciences, Insubria University of Varese, Varese, Italy
}

\begin{abstract}
The aim of the work is to assess current solid waste management (SWM) and wastewater treatment (WWT) in the county of Sibiu, Romania. Sibiu is a region where industrialization and tourism are spreading constantly, while pollution monitoring and the introduction of circular economy (CE) principles are still lacking. The environmental issues are mostly due to the absence of reliable sanitation systems, in particular for what concerns sewage sludge treatment. Moreover, Organic fraction from selective collection of municipal solid waste is still missing, since it is disposed of directly to landfill, increasing environmental pollution and contributing considerably to global warming. As a result, SWM and WWT should be improved at the same time, as sludge requires specific handlings in order to be safety disposed. The objective of the study is to investigate the introduction of affordable technological facilities able to treat sludge and the organic fraction of municipal solid waste, recovering, at least, the energy required for the working phase of the treatment plants. Anaerobic digestion resulted viable, but the organic fraction full stream collection seems to be the only way to have a significant energy recovery. From the financial point of view, the feasibility of this co-treatment option could count on specific opportunities that Romania has in the frame of the European Union context.
\end{abstract}

\section{Introduction}

The declared aim of the EU Sustainable Development Strategy is to work towards improvements of the life quality, both for the present and the future [1]. Despite the progress in the recent years, it is a fact that Romania's economy still relies on intensive consumption of resources. The society and the administrations have yet to develop a shared vision, and so the natural capital faces the risk of damages that may become irreversible [2].

The relentless deterioration of natural resources, which affect many emerging countries due to economic improvements boosted by national policies [3], and the need of their conservation requires a good waste and wastewater management, an increasing recovery of wastes and their reduction $[4,5,6]$. In this sense, according to European regulations, the waste

\footnotetext{
* Corresponding author: vincenzo.torretta@uninsubria.it
} 
hierarchy of prevention, re-use, recycling, recovery for other purposes such as energy and disposal should be applied [7].

Wastewater and solid waste are to be considered as new sources of energy and materials that can be used in a circular economy perspective, also for developing and rural regions $[6,8$, 9]. European directives transposed into Romanian legislation led to a new approach to the waste problem, focusing on the need of natural resources protection, costs management reduction and effective solutions to reduce pollution [10-12]. The general framework waste regime in Romania stated on the Legea $n r .211 / 2011$ on waste regime [13].

For the creation, organization and operation in the common interest of sanitation services of a national waste management system, Romania formed administrative-territorial units called Asociatia de Dezvoltare Intercomunitaria (ADI) [14], and developed waste management plans at national, regional and county level.

In the case study the focus is on municipal solid waste (MSW), which is generated by: households, commercial activities and other sources whose activities are similar to those of households and companies. The current management of urban waste generates negative impact on the environment both in the presence of household waste and industrial waste, since most of the MSW is disposed of in landfills. Landfills are a source of air pollution (emissions of methane), surface water pollution and degradation of soil quality through the percolation of hazardous liquids that cause low soil fertility, also at great distances [15-18].

The main problems identified in the environmental assessment of Sibiu consist of:

- waste management, with focus on Organic Fraction of MSW (OFMSW);

- sludge management.

Nowadays in the city of Sibiu the OFMSW is not recovered in any way, and it is instead disposed of in landfills, management which should be avoid, as stated in the Council Directive 1999/31/EC. However some proposals where put forward [19].

In addition to that, as reported in the next paragraphs, the sludge from the wastewater treatment station are just stored in the area adjacent the WWTP and not recovered.

For all these reasons, it is necessary to find another way to manage the OFMSW of the city of Sibiu and the WWTP sludge. Thus, the aim of this work is to offer practical (and replicable) proposals to improve urban waste management, focusing in particular on its organic fraction, integrating it with the appropriate sewage sludge management, in order to reduce the environmental impacts and to recover resources and energy. This integrated approach is considered an opportunity both as national strategy and at local level [20,21].

\section{Materials and methods}

Sibiu is located in the southern part of Transylvania, and extends for an area of $5,432.5 \mathrm{~km}^{2}$ ( $2.3 \%$ of the country), with a population of about 425,000 inhabitants, $66 \%$ of which are urban citizens and the others live in rural areas. The capital of the county, Sibiu, has about 148,000 inhabitants. The status quo of the economy of the Sibiu County is analysed in the Annual report of the State of the Environment, which is published every year [22]. At the end of 2012, the county could count 10,031 active companies.

The main activities in this area are trade, manufacture, scientific profession, agriculture and livestock. Sibiu has also a significant agricultural potential thanks to the total of about 117,000 hectares of arable land, and about 108,000 hectares of pasture land [7]. The forest department in Sibiu also plays an important role, with an area of about 112,000 ha of land. The GDP/per capita is $6,837 €$, higher than the national one $(5,454 €)$. The unemployment rate is low and around $5.4 \%$ with an average monthly salary of just over $300 €$. There is an environmental monitoring network divided by different areas: air quality, drinking water, wastewater and waste, which are included in the annual report $[2,22]$. 
In 2014, the County had the following functional facilities for MSW management:

- 3 transfer and sorting stations for household waste

- 1 sorting station for household waste

- 1 transfer and compost station

- 1 station sorting and composting of household waste

- 1 composting station

Table 1 illustrates the situation of household waste collected separated or mixed. The waste was landfilled in the Sibiu landfill. Selective collection (SC) is one of the key steps of a modern waste management, in order to transform what is recyclable into useful products. In the Sibiu County, SC was extended with the implementation of five waste management projects financed by PHARE CES 2003-2005 [23]. Following the closure of the noncompliant landfills in Sibiu, an extensive awareness campaign was conducted in order to connect the sanitation services operator to the households, especially in the rural areas. For biodegradable waste, awareness activities in schools were also organized, distributed individual compost units, in order to decrease the amount of waste sent to the landfills.

As a matter of a fact, in 2016, in the area of the city of Sibiu, there are no bins for SC. The whole waste is collected together mixed in just one type of bin. There are two companies in charge of collecting waste. The citizens can choose to make use of the service of either company for their waste. Most of the projects about SC started in 2014 lasted for only few months, because of the arising of technical and political problems. Nowadays, since 2016, $\mathrm{SC}$ is in a law impasse after the awarding of the contract to a firm. Another company challenged the result of the competitive procedure and now it is currently awaiting trial.

Table 1. Household waste (collected separately and mixed) (2008-2012).

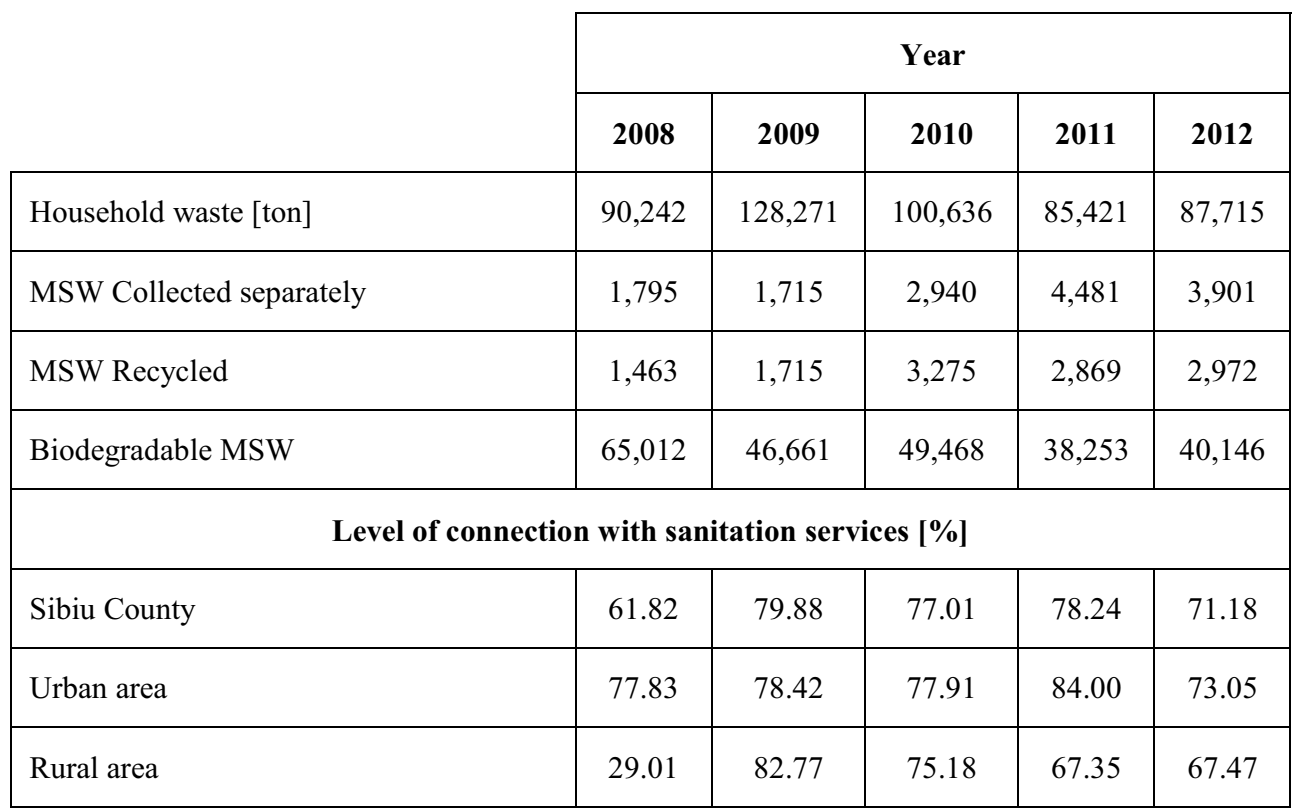

The wastewater treatment station has a capacity of 225,000 Equivalent Inhabitants (EI), but nowadays it serves $180,000 \mathrm{EI}$. It is a conventional activated sludge treatment plant, with processing of sludge with thickening and anaerobic digestion. Currently the sludge from the wastewater treatment plant in Sibiu is disposed of on the left bank of the Cibin river. Here the natural drying of the sludge takes place. The total area of the deposit is approximately 2 hectares, divided in 1.35 ha of the deposit itself and 0.65 ha of access and perimeter roads [24]. The daily quantity of sludge collected by the station is shown in the Table 2. 
Table 2. Flow and moisture of the sludge [19]

\begin{tabular}{|l|c|c|}
\hline Parameter/Stage & & Value \\
\hline Daily sludge flow & {$\left[\mathrm{m}^{3} / \mathrm{day}\right]$} & 180 \\
\hline Hourly sludge flow & {$\left[\mathrm{m}^{3} /\right.$ hour $]$} & 8.7 \\
\hline Final polymerization step & {$\left[\mathrm{H}_{2} \mathrm{O}\right.$ content $\left.\%\right]$} & 75.0 \\
\hline
\end{tabular}

The sludge is left on the area near the station for an unstated time and presently there is not a plan to recover them. In 2016, the managers of the WWTP claim that this is not an imminent problem. The main reason is the lack of capital that they would need in order to launch a new project. In Table 3 the characteristics of the digester are reported.

Table 3. Characteristics of the digester.

\begin{tabular}{|l|c|c|}
\hline Parameter & & Value \\
\hline $\mathrm{B}_{\mathrm{r}}:$ Maximum organic loading rate & $\mathrm{kgvvs} \mathrm{m}^{-3} \mathrm{day}^{-1}$ & 4 \\
\hline $\mathrm{V}_{\text {f: }}$ Available digester volume & $\mathrm{m}^{3}$ & 900 \\
\hline Tf: Required hydraulic retention time & day & 40 \\
\hline Qks: Daily amount of digester sludge & $\mathrm{m}^{3} / \mathrm{day}$ & 15 \\
\hline
\end{tabular}

The proposal of this study is to recover the OFMSW and solve the problem of the sludge management using the digester as a co-digestion unit to treat these two kinds of waste, as suggested by other studies [4, 25-28].

Potentially, this would allow producing the required biogas for the thermal drier in which the waste would be modified in order to make the resulting material appealing for a cocombustion in cement kilns. A flowchart of the process is shown in Figure 1 [29]. Two different operative scenarios have been selected: case A and B:

- Case A: the starting idea is to collect the OFMSW from the city centre of Sibiu, starting from the markets of vegetable and fruit, and then from the restaurants and bars. The choice of these places where to begin the collection is based on their convenience. In fact the markets' waste is mainly OFMSW, and the two markets produce big quantities of it. The two fruit and vegetable markets are Cibin and Rahova. They are in the area around the city center. Other than the markets, the OFMSW, can be easily collected from the pubs, bars and restaurant.

- Case B: it is taken into account the possibility to improve SC of the OFMSW from civil residences. The waste production per capita is of $0.83 \mathrm{~kg} \mathrm{inh}^{-1} \mathrm{~d}^{-1}$, where the weight percentage of the organic fraction is equal to $70 \%$ and a moisture of $70 \%$. From the calculation, it results a total quantity of OFMSW equal to $86 \mathrm{t} / \mathrm{d}$.

Presently, in the historic center of Sibiu 93 pubs/bars/restaurants of medium small dimension, and 2 big ones are located. Each of the smaller services is supplied with 2 bins of a 1201 volume in which the OFMSW is gathered. All of these bins are then collected weekly by the waste company in charge.

The same happens for the two big restaurants, which have five bins, because of their intense OFMSW production. The compactness of the waste in these bins can be estimated as the one in the markets' bins, and so of around $300-350 \mathrm{~kg} / \mathrm{m}^{3}$. 


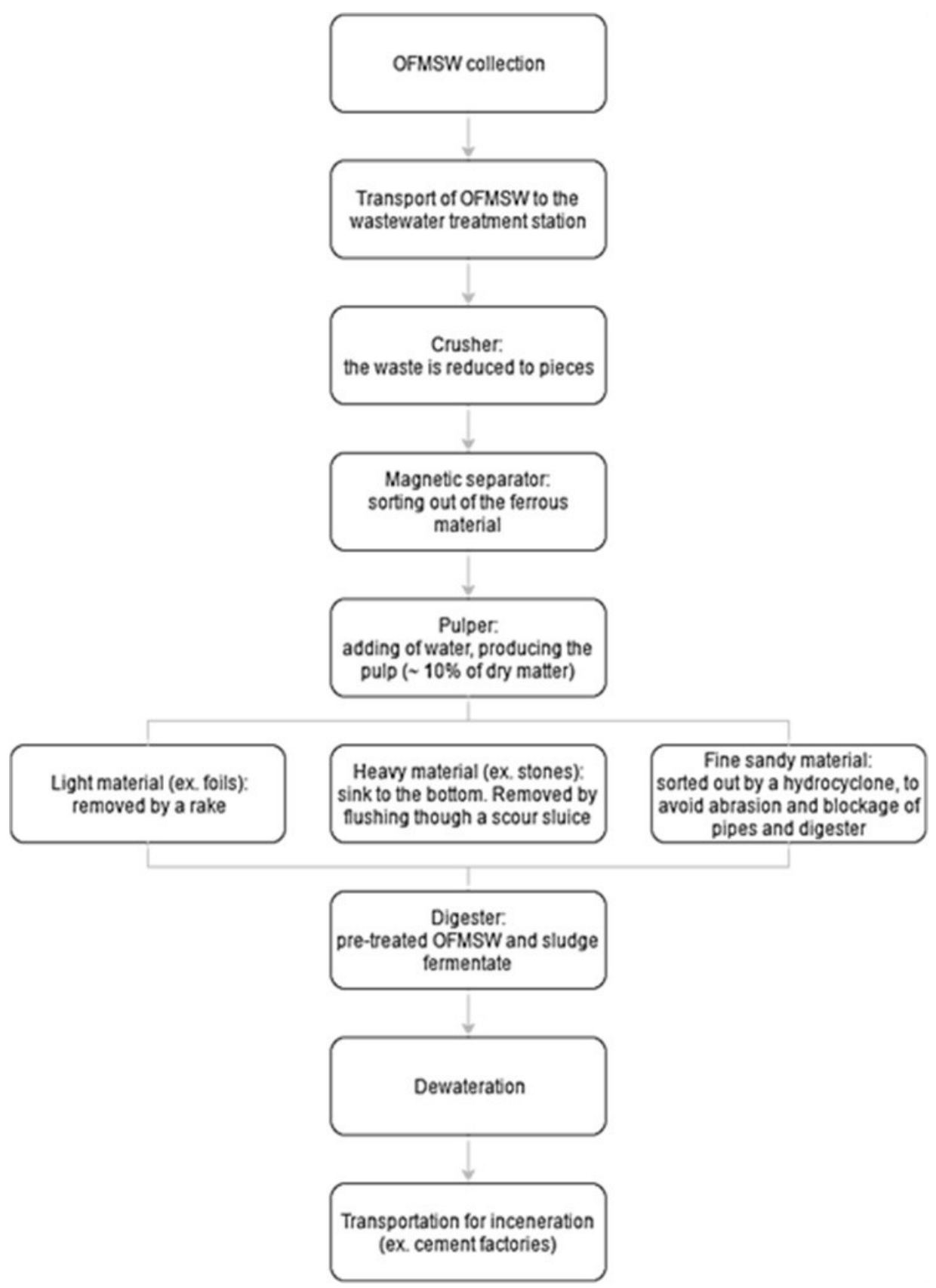

Fig. 1. Flowchart of the co-digestion and drying of the waste.

The total quantity of OFMSW that could be collected from the historical center of Sibiu is about 17 ton/month, considering the lowest compactness, and circa 20 ton/month, considering the highest. This estimation is done calculating only the $60 \%$ of the bin as full, doing an average throughout the year. Adding the fraction from the markets and the one from the pubs/bars/restaurants the total quantity of OFMSW per month is between 40 and 53 ton/month. The data referring to the Case A are reported in Table 4. 
Table 4. Data related to the two markets, bars and restaurants.

\begin{tabular}{|c|c|c|c|c|c|c|c|}
\hline Source & Nr of bins & $\begin{array}{c}\text { Capacity } \\
\mathbf{m}^{3}\end{array}$ & $\begin{array}{c}\text { Volume } \\
\mathbf{m}^{3} / \text { month }\end{array}$ & \multicolumn{2}{|c|}{$\begin{array}{c}\text { Density } \\
\mathrm{kg} / \mathrm{m}^{3}\end{array}$} & \multirow{2}{*}{\multicolumn{2}{|c|}{$\begin{array}{c}\begin{array}{c}\text { Weight } \\
\text { ton/month }\end{array} \\
20\end{array}$}} \\
\hline Cibin Market & - & - & 1.1 & 300 & 350 & & \\
\hline Rahova Market & - & - & 1.1 & 300 & 350 & & \\
\hline \multicolumn{6}{|c|}{ TOTAL FROM MARKETS } & \multicolumn{2}{|c|}{33} \\
\hline \multicolumn{8}{|c|}{ Bar - Restaurants (B-R) } \\
\hline B-R of big dimesion & 5 & 0.12 & 2.1 & 300 & 350 & 0.43 & 0.50 \\
\hline B-R of small dimesion & 2 & 0.12 & 0.96 & 300 & 350 & 0.17 & 0.20 \\
\hline \multicolumn{6}{|l|}{ TOTAL FROM B-R } & 40 & 53 \\
\hline
\end{tabular}

\section{Results}

The current situation in Sibiu shows no critical issues in the regards of air quality and it does not prevent an additional combustion of biogas. The current output from the wastewater treatment plant does not present any issue, since there is a good pollutants removal. Of great importance is the analysis of the nitrogen pollutants in the wastewater output from the station, because the addition of a thermal drying increases the load of nitrogen to the system because of the condensation of moist air as an output of the dryer. From the drinking water side, there are no critical environmental issues; in fact the study shows a total separation of the sector from the purification of waste water due to the type of sources used. As a conclusion, there are no critical environmental issues that would stop the construction of the new system.

Moving to the results connected to the proposal, Table 5 reports the amount of OFMSW in the two scenarios, to be treated in co-digestion with sludge, and its characteristics.

Table 5. OFMSW in the two scenarios.

\begin{tabular}{|c|c|c|c|}
\hline & & Case A & Case B \\
\hline \multicolumn{4}{|c|}{ Sludge: } \\
\hline EI served by the WWTS & EI & 180,000 & 180,000 \\
\hline Sludge production & $\mathrm{g}_{\mathrm{TS}} /$ inhab d & 100 & 100 \\
\hline Sludge density & $\mathrm{g} / 1$ & 1,000 & 1,000 \\
\hline Sludge moisture & & $97 \%$ & $97 \%$ \\
\hline Daily sludge input & $t / d$ & 180 & 180 \\
\hline \multicolumn{4}{|c|}{ OFMSW: } \\
\hline Daily urban waste production & $\mathrm{kg}_{\mathrm{inh}}{ }^{-1} \mathrm{~d}^{-1}$ & & 0.83 \\
\hline OFMSW percentage in the UW & & & $70 \%$ \\
\hline Residents in Sibiu & inh & & 147,245 \\
\hline Daily OFMSW production & toFMSw/d & 1.77 & 87.32 \\
\hline
\end{tabular}




\begin{tabular}{|c|c|c|c|}
\hline & \multirow{3}{*}{$\begin{array}{c}\text { Case A } \\
70 \%\end{array}$} & \multirow{3}{*}{$\begin{array}{c}\text { Case B } \\
70 \%\end{array}$} \\
\hline & & & \\
\hline OFMSW moisture & & & \\
\hline \multicolumn{4}{|c|}{ Total quantities in input: } \\
\hline VS in input & $\mathrm{t}_{\mathrm{vs}} / \mathrm{d}$ & 4.28 & 28.67 \\
\hline NVS in input & $\mathrm{t}_{\mathrm{NVS}} / \mathrm{d}$ & 1.65 & 2.93 \\
\hline TS in input & $\mathrm{t}_{\mathrm{TS}} / \mathrm{d}$ & 5.93 & 31.59 \\
\hline Water in input & $\mathrm{t}_{\mathrm{H} 2 \mathrm{O} / \mathrm{d}}$ & 175.84 & 235.72 \\
\hline Biogas conversion: & & $50 \%$ of VS & $50 \%$ of VS \\
\hline \multicolumn{4}{|c|}{ Total quantities in output: } \\
\hline VS in output & $\mathrm{t}_{\mathrm{vs}} / \mathrm{d}$ & 2.14 & 14.33 \\
\hline NVS in output & $\mathrm{t}_{\mathrm{NVS}} / \mathrm{d}$ & 1.65 & 2.93 \\
\hline TS in output & $\mathrm{t}_{\mathrm{TS}} / \mathrm{d}$ & 3.79 & 17.26 \\
\hline Water in output & $\mathrm{t}_{\mathrm{H} 2 \mathrm{O} / \mathrm{d}}$ & 175.84 & 235.72 \\
\hline Moisture in output & & $98 \%$ & $93 \%$ \\
\hline
\end{tabular}

The following tables show the comparison between the current dehydration and the target for the sludge, if thermally dried, the additional production of biogas by co-digestion and the energy balances, for the additional stream of OFMSW.

Table 6. Comparison between the current dehydration and the target level.

\begin{tabular}{|l|c|c|c|}
\cline { 3 - 4 } \multicolumn{2}{c}{} & Case A & Case B \\
\hline Mechanical dehydratation :TS in output & - & $25 \%$ & $25 \%$ \\
\hline Mechanical dehydratation :Substance quantity in output & $\mathrm{t} / \mathrm{d}$ & 15.15 & 67.94 \\
\hline Dryer: Target Moisture of the output material & & $10 \%$ & $10 \%$ \\
\hline Dryer: Water in input & $\mathrm{t} / \mathrm{d}$ & 11.36 & 50.95 \\
\hline Dryer: Water in output & $\mathrm{t} / \mathrm{d}$ & 0.42 & 1.89 \\
\hline Dryer: Water to be evaporated & $\mathrm{t} / \mathrm{d}$ & 10.94 & 49.06 \\
\hline & $\mathrm{kg} / \mathrm{h}$ & 455.99 & $2,044.37$ \\
\hline
\end{tabular}

Table 7. Addional production of biogas by co-digestion.

\begin{tabular}{|l|c|c|c|}
\hline & & Case A & Case B \\
\hline Biogas yield & $\mathrm{Nm}^{3} / \mathrm{t}_{\text {OFMSW }}$ & 150 & 150 \\
\hline Daily biogas quantity & $\mathrm{Nm}^{3}{ }_{\text {biogas }} / \mathrm{d}$ & 265 & 12,832 \\
\hline $\mathrm{CH}_{4}$ quantity in biogas & - & $60 \%$ & $60 \%$ \\
\hline $\mathrm{CH}_{4}$ quantity & $\mathrm{Nm}^{3}{ }_{\mathrm{CH} 4} / \mathrm{t}_{\text {OFMSW }}$ & 90 & 90 \\
\hline Daily $\mathrm{CH}_{4}$ quantity & $\mathrm{Nm}^{3}{ }_{\mathrm{CH}} / \mathrm{d}$ & 159 & 7,699 \\
\hline
\end{tabular}


Table 8. Dryer energy demand [30] and the energy production in the co-generator engine (CHP).

\begin{tabular}{|c|c|c|c|}
\hline & \\
\hline & & Case A & Case B \\
\hline Dryer energy demand & $\mathrm{kWh} / \mathrm{kg}_{\mathrm{H} 2 \mathrm{O}}$ & \multicolumn{2}{|c|}{$\mathrm{kWh} / \mathrm{d}$} \\
\hline Electric energy demand & $0.03-0.5$ & $328-1,642$ & $1,472-7,360$ \\
\hline Thermal energy demand & $0.8-0.9$ & $8,755-9,849$ & $39,252-44,158$ \\
\hline Energy production in the CHP & $\mathrm{kWh} / \mathrm{Nm}^{3}$ biogas & \multicolumn{2}{|c|}{$\mathrm{kWh} / \mathrm{d}$} \\
\hline Electric energy production & $1.8-2$ & $477-530$ & $23,098-25,665$ \\
\hline Thermal energy production & $2-3$ & $530-795$ & $25,665-38,497$ \\
\hline
\end{tabular}

The demand of thermal energy is greater than its production in co-generation. On the other hand, the production of electric energy covers the demand. For the lack of thermal energy, it is necessary to do a partial co-generation using only a fraction of the biogas generated from the co-digestion (supposing that the role of the present sludge stream is neutral). The remaining part of the biogas is thus used to generate thermal energy using a heater. An alternative could be the drying of only a percentage of sludge. Typically, the final solid content in the sector is $90 \%$, but, through a partial bypass of the drier, it is possible to modulate the final solid content down to a target level suitable for balancing the thermal energy demand. This must be done taking into account the final destination of the output. Codigestion of OFMSW and sludge could suffer from a bad quality of sludge in terms of heavy metal content, if a biological destination would be planned. The alternative could be a combustion in industrial burners as the ones of cement factories. In this case the problem of heavy metal presence in the sludge could be less stringent, but the case of partial drying should be deeply analysed as the lower heating value of the dried output could be no longer compatible with an industrial furnace.

\section{Conclusions}

The improvement of the waste management systems and sewage sludge can be obtained through an assessment of the current environmental loads and the possibility that the environment has to support other treatment plants. A decisive step in the implementation of sustainability principles is the application of Circular Economy. In this frame, the current situation assessment on the waste and sewage sludge from WWTP management in a developed area in Romania has been described and the main environmental pressures were analyzed in order to find out any criticality.

This was followed by the setting of a proposal to adjust the current management system of waste, with a focus on organic waste and sewage sludge. The feasibility of interventions is affected both by the environmental and financial feasibility. After the environmental assessment no critical issues were found. Regarding the financial aspect of the project, it is linked to the availability of funding opportunities that in Romania is much easier than in other countries of the European Community (e.g.: Structural Funds 2014-2020, European Regional Development Fund and Operational Program for Big Infrastructure).

Some specific issues related to the composition of sludge should be deeply analysed taking into account the final destination of the co-digested output. 
The authors acknowledge the co-tutors dr. Elena Cristina Rada and prof. Lucian Ionel Cioca, and the Erasmus+ Programe for the support during the development of the research and during the stage in Romania.

\section{References}

1. $* * *$ http://ec.europa.eu/environment/eussd/, accessed 04.03.2017

2. *** Raport anual privind starea mediului in judetul Sibiu (Ministerul Mediului, Apelor si Padurilor, 2014)

3. M. Ragazzi, R. Catellani, E.C. Rada, V. Torretta, X. Salazar-Valenzuela, Sustainability, 6, 1 (2014)

4. E.C. Rada, M. Ragazzi, S. Villotti, V. Torretta, V. Waste Manag. 34, 5 (2014)

5. E.C. Rada, M. Ragazzi, G. Ionescu, G. Merler, F. Moedinger, M. Raboni, V. Torretta, Energ. Procedia, 50 (2014)

6. G. Ionescu, E.C. Rada, L.I. Cioca. Environ. Eng. Manag. J. 14, 11 (2015)

7. *** Directive 2008/98/EC of the European Parliament and of the Council of 19 November 2008 on waste and repealing certain Directives (European Council, 2008)

8. V. Torretta, F. Conti, M. Leonardi, G. Sustainability, 4 (2012)

9. R.D. Ionescu, M. Ragazzi, L. Battisti, E.C. Rada, G. Ionescu, WIT Transact. Ecol. Environ. 176 (2013)

10. S. Di Leo, M. Salvia, Renew Sustain. Energ., Rev. 68 (2017)

11. A.N. Iuga, IOP Conf. Ser. Mate. Sci. Eng., 161, 1 (2016)

12. C. Iacoboaea, O. Luca, F. Petrescu, Theor. Empirical Res. Urban Manag., 8, 4 (2013)

13. ${ }^{* * *} \mathrm{http}: / /$ ec.europa.eu/environment/waste/framework/, accessed 04.03.2017

14. *** http://www.adiecosibiu.ro/despre-noi.html, accessed 04.03.2017

15. V. Torretta, N. Ferronato, I.A. Katsoyiannis, A.K. Tolkou, M. Airoldi, Sustainability, 91 (2017).

16. $* * *$ Council Directive 1999/31/EC of 26 April 1999 on the landfill of waste (European Council, 1999)

17. E.C. Rada, I.A. Istrate, V. Panaitescu, M. Ragazzi, T.M. Cirlioru, T. Apostol, Environ. Eng. Manag J. 9, 4 (2010)

18. L.I. Cioca, L. Ivascu, E.C. Rada, V. Torretta, G. Ionescu G. Sustainability. 7 (2015)

19. R. Ciudin, C. Isarie, L.I Cioca, V. Petrescu, V. Nederita, E. Ranieri, E., UPB Sci. Bull., Series D, 76, 3 (2014)

20. G. Silvestre, A. Bonmati, B. Fernandez, Waste Manag, 43 (2015)

21. B. Morero, R. Vicentin, E.A. Campanella, Waste Manag., 61 (2017)

22. *** Raport anual privind starea mediului în judetul Sibiu (Ministerul Mediului, Apelor si Padurilor, 2013).

23. *** http://www.adrcentru.ro/Detaliu.aspx?t=PFPhareImpleID=32, accessed 04.03.2017

24. E. Trulli, V. Torretta. Environ. Technol., 36, 12 (2015)

25. G. Andreottola, M. Ragazzi, P. Foladori, R. Villa, M. Langone, E.C. Rada, E.C., UPB Sci. Bull. Series C, 74, 1 (2012)

26. P. Arnò, S. Fiore, V. Verda, Energy, 122 (2017)

27. V. Cabbai, N. De Bortoli, D. Goi, Waste Manag., 49 (2016)

28. G. Silvestre, A. Bonmatí, B. Fernández, Waste Manag. 43 (2015)

29. M. Krupp, J. Schubert, R. Widmann, Waste Manag. 25, 4 (2005)

30. $* * * \mathrm{http}: / / \mathrm{www} \cdot h u b e r . d e /$, accessed 04.03.2017 